\title{
Host Range Studies of Soybean Mosaic Virus
}

\author{
H.V. Nandakishor ${ }^{1}$, B. Kumaraswamy ${ }^{1 *}$, S.S. Mane $^{1}$ and G. Amrutha Veena ${ }^{2}$ \\ ${ }^{1}$ Department of Plant Pathology, Dr. PDKV, Akola, 444104, Maharashtra, India \\ ${ }^{2}$ Department of Plant Pathology, Achaya N. G. Ranga Agriculture University, \\ Andhra Pradesh, India \\ *Corresponding author
}

\section{A B S T R A C T}

Keywords

Soybean, SMV, Solanaceae,

Cucurbitaceae, Leguminosae

Article Info

Accepted:

04 June 2017

Available Online:

10 July 2017
The SMV causing mosaic in soybean was readily transmissible through sap, seed and aphids. Sap transmission of the SMV on soybean cv. JS-335 produced characteristic symptoms such as dark green colour of leaves, mosaic and mottling symptoms, crinkling, leaf puckering of leaves. The soybean mosaic virus infected a wide range of the host plants. five species belonging to the families of Solanaceae, Cucurbitaceae, Leguminosae and Caricaceae induced most conspicuous symptoms like mottling symptoms, common symptoms such as mottling, crinkling of leaves, leaf puckering, dwarfing and top necrosis etc. The plant species belonging to the families Crucifereae, Amarantheceae and Malvaceae could not exhibit any symptoms.

\section{Introduction}

Soybean [Glycine $\max$ (L.) Merrill], 'Queen of Pulses', a native of Eastern Asia belongs to the family Leguminosae, subfamily Papilionoideae and tribe Phaseolae. Soybean is considered as a 'Golden bean', 'Miracle bean', 'Agriculture's Cinderella' and Wonder crop' of the $20^{\text {th }}$ Century' due to its qualities such as high protein (40\%), good amount of carbohydrates (35 0/0), oil (20\%) and ash (5\%) content on oven dry basis. Soybean is known to be naturally infected by at least 50 viral diseases belonging to different groups (Sinclair, 1992). In India, so far 11 viruses have been reported to occur on soybean (Mali, 1995). Among the viral diseases, soybean mosaic virus (SMV) (Mali, 1995) seems to be much of prevalence. Clinton
(1915) reported the occurrence of soybean mosaic virus for the first time in world. In India the occurrence of soybean mosaic virus was reported from New Delhi by Nariani and Pingaley (1960).

Later its occurrence was reported from Tamil Nadu (Usman et al., 1973), Uttar Pradesh (Singh et al., 1976) and Karnataka (Naik and Murthy, 1992). The primary leaves of infected plant curled down words, petioles and internodes shortened and plants were highly stunted. The virus was established on glasshouse grown soybean plants variety JS335 by mechanical inoculation. Results of detailed studies made on this disease are reported in this study. 


\section{Materials and Methods}

A virus inoculum for sap transmission was prepared by grinding the leaves of symptomatic plants in $0.1 \mathrm{M}(\mathrm{pH}$ 7.2) Phosphate buffer. The sap was then clarified by straining through two fold muslin cloth and inoculated to the first true leaf of the seedlings by previously dusted carborandum 600 mesh as a abrassive.Immediately after inoculation, the leaves were washed thoroughly with tap water to remove excess of inoculum and abrassive. The plants were assayed two and four weeks after inoculation for symptomatology studies.

For each test plant, healthy seedlings as control were also maintained to compare with the symptomatic plants. All the inoculated plants were maintained in an insect proof cage house with proper labelling till the development of symptoms. For host range studies, 25 plant species belonging to seven different families were tested by sap inoculation. The plants, which did not show any visible symptoms of infection, were back index on test plants of Chenopodium amaranticolor.

\section{Results and Discussion}

The data tabulated in table 1 showed that species of different family reacted with either local symptoms or systemic symptoms showing that the virus has limited host range. The other plants were inoculated but neither had they showed any symptoms nor was the virus recovered from them by back indexing on C. amaranticolor.

In order to determine the host range of SMV fourty eight plant species belonging to nine families viz., Solanaceae, Cucurbitaceae, Amaranthaceae, Compositae, Leguminosae, Cruciferaceae, Chinopodiaceae, Caricaceae and Malvaceae were mechanically inoculated with standard inoculum of SMV for sap transmission was prepared by grinding the leaves of symptomatic plants in $0.1 \mathrm{M}(\mathrm{pH}$ 7.2) Phosphate buffer. In host range studies, the infection of virus under study was observed on four plant species belonging to the families of Solanaceae, Cucurbitaceae, Leguminosae and Caricaceae. Rest of plant species belonging to three families viz., Crucifereae, Amarantheceae and Malvaceae were found non hosts to the infection by soybean mosaic virus. This indicates that the virus has a wide host range.

The data obtained (Table 1) indicated that soybean mosaic virus could infect one plant species belonging to family Chinopodiaceae and three plant species of Leguminaceae including soybean. The virus induced small chlorotic local lesion on Chenopodium amaranticolor 10-12 days after inoculation. Whereas, dark green areas interspersed with light green back ground and diffused mosaicmottling symptoms developed on the inoculated young leaves of Dolichos lab-lab, 13-15 days after inoculation (Fig. 2-J). Leaves of Vigna unguiculata (L.) show Systemic symptoms like Chlorotic spots along with yellowing after 15-16 days after inoculation. These symptoms were masked when the leaves reach maturity. The rest of plant species tested were not infected indicating limited host range of the virus.

The result (Table 1) of host reactions against the soybean mosaic virus indicated that the virus had a wide host range and was able to infect Glycine $\max$ (L) Merr, Vigna unguiculata (L), Cucumis sativus, Dolichos lablab, Phaseolus vulgaris, Datura stramonium, Chenopodium amaranticolor. Among the different hosts, soybean (Glycine max) recorded 100 per cent transmission and expressed the symptoms like mosaic, distorted leaf and chlorotic spots with 15 days incubation period (Figs. 1 and 2). 
Fig.1 Symptoms on cucumber sap inoculated with SMV
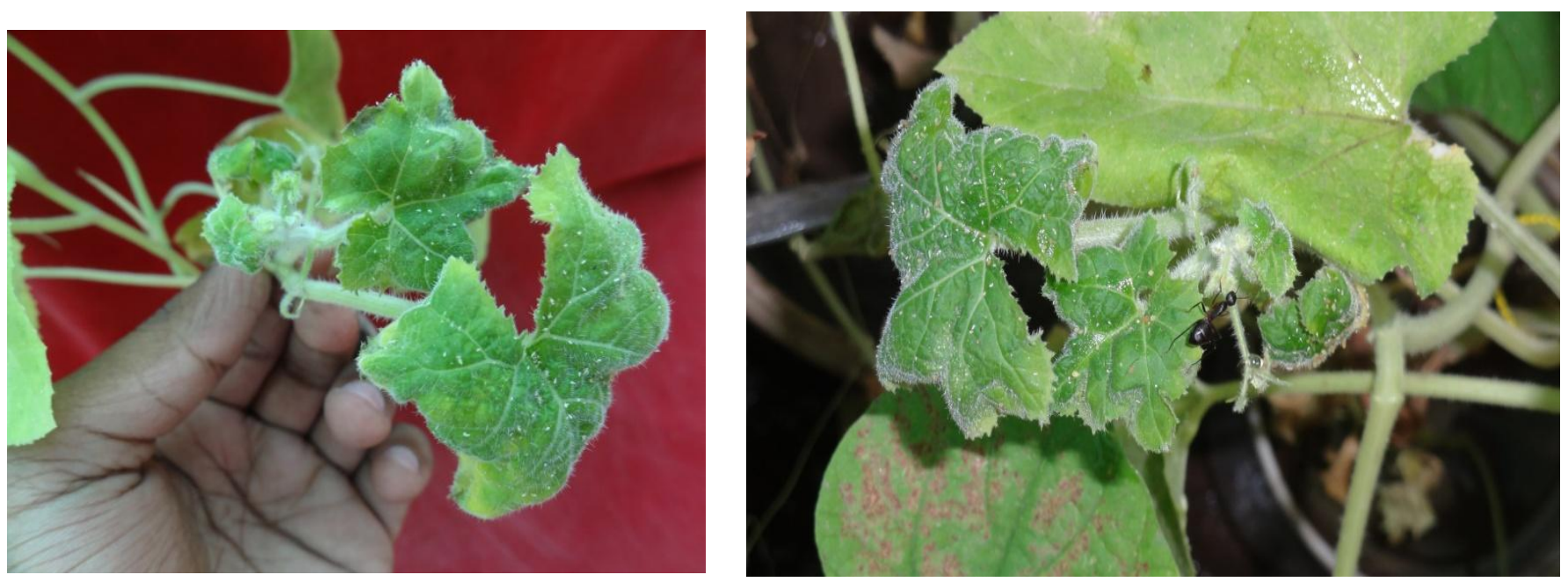

A1 and A2. Cucumber plant showing severe curling symptoms after sap inoculation with SMV

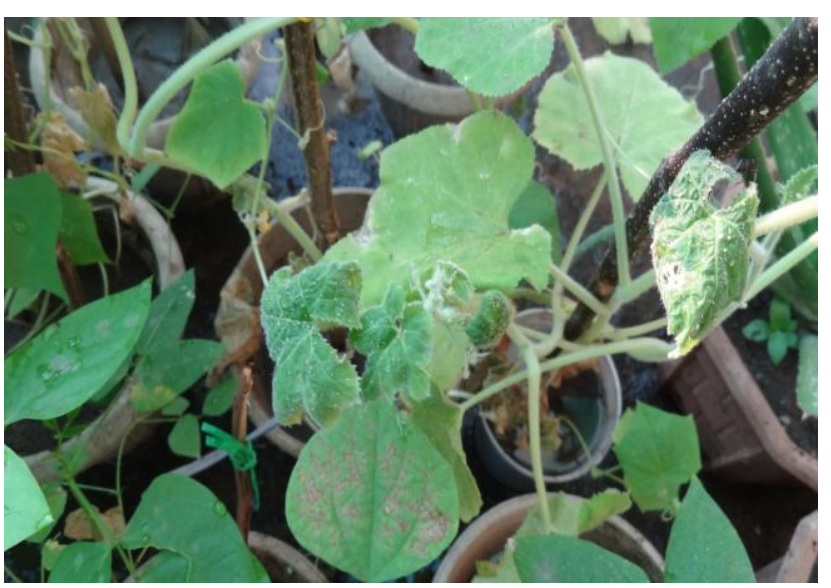

B. Diseased cucumber plant showing mosaic and mottling

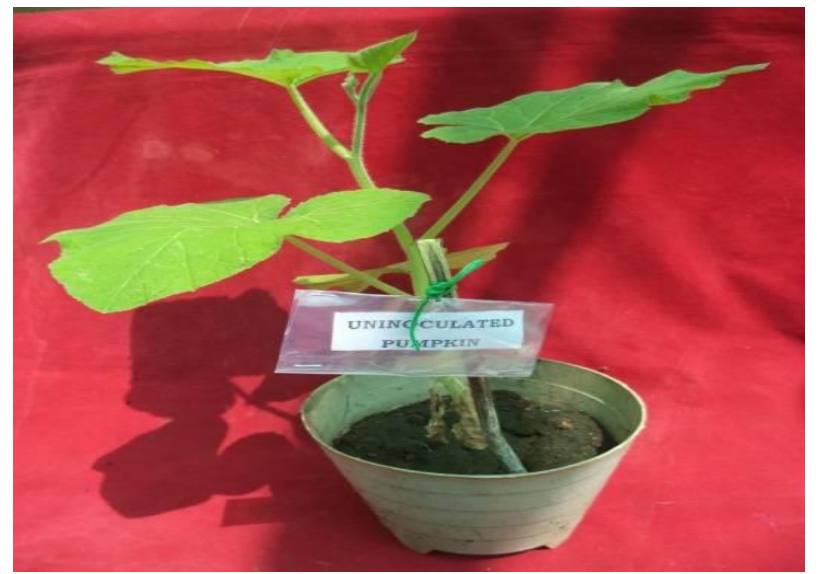

C. Healthy cucumber plant

Fig.2 Symptoms on different hosts sap inoculated with SMV

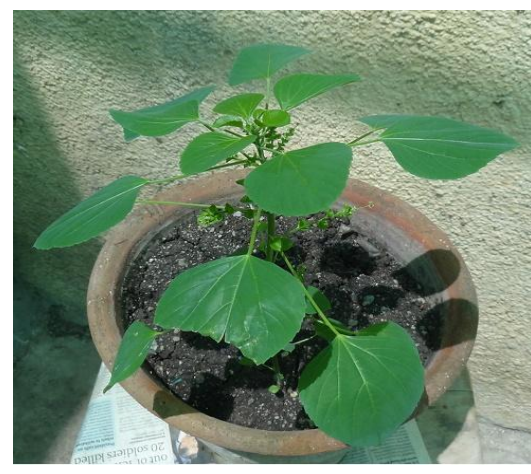

D. Healthy datura plant

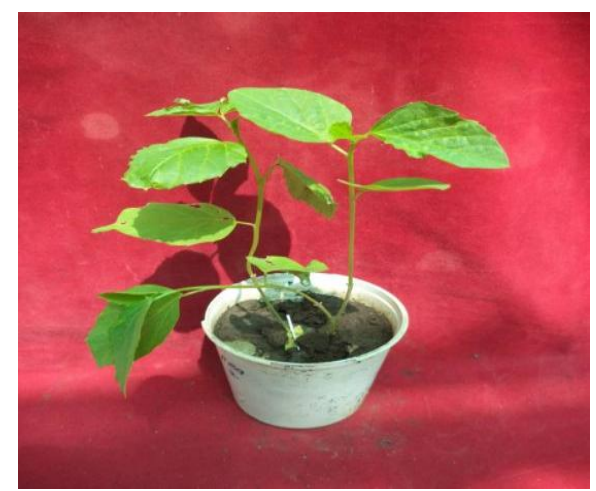

E. Infected datura showed chlorotic

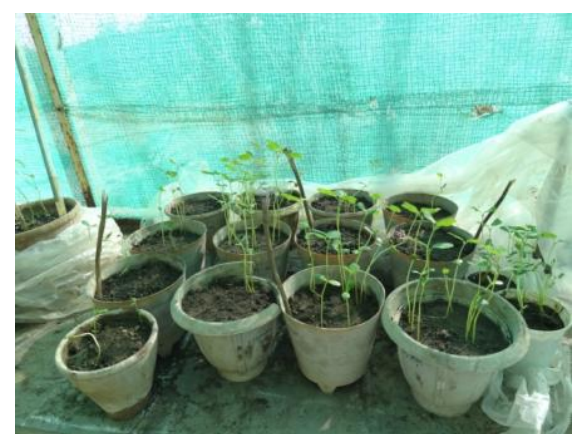

F. Maintenance of propagative host inside cage house 


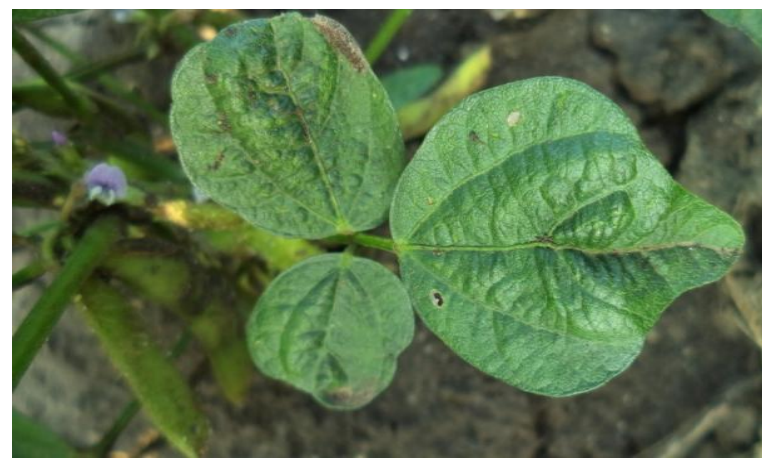

G. Trifoliate soybean leaf showing mottling symptoms

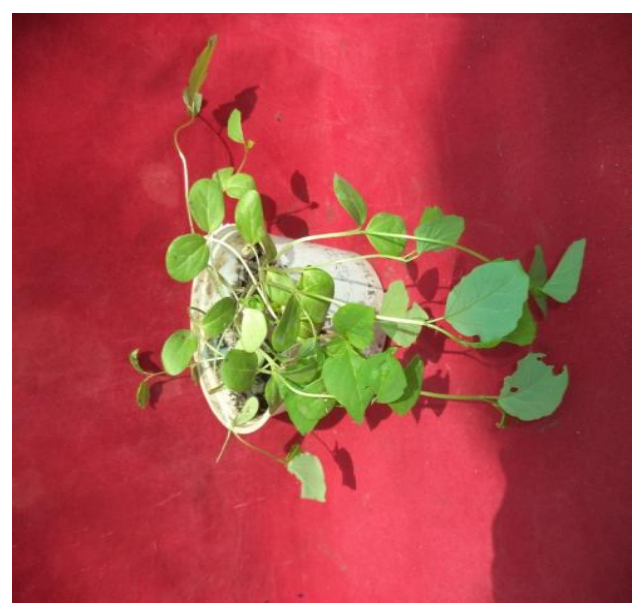

I. Pea showing light green mosaic

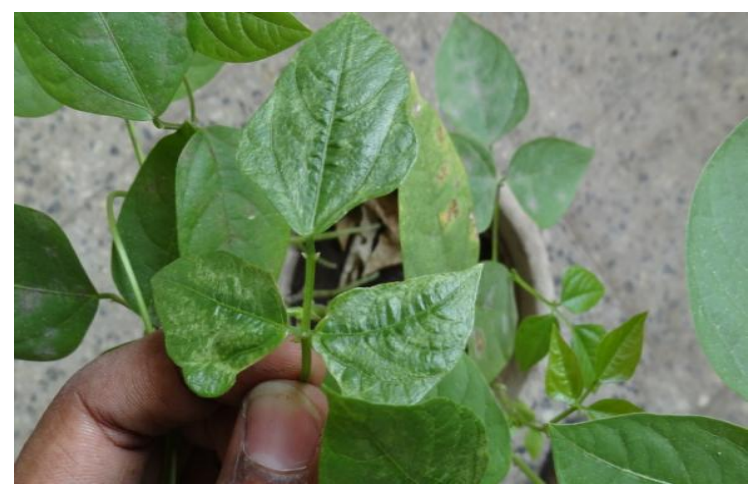

H. Cowpea plant showing chlorotic and vein clearing

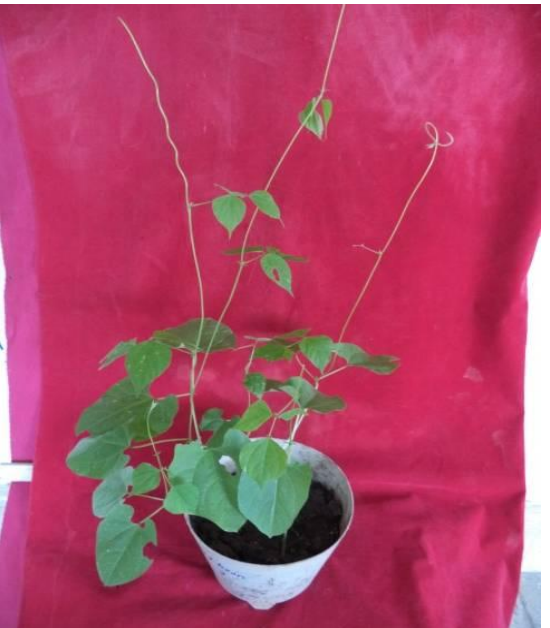

J. Dolichous bean showing dark green

Table.1 Reactions of different hosts against virus associated with soybean mosaic disease

\begin{tabular}{|c|c|c|c|c|c|c|c|}
\hline \multirow{2}{*}{$\begin{array}{l}\text { Sl. } \\
\text { No }\end{array}$} & \multirow{2}{*}{$\begin{array}{l}\text { Name of the host } \\
\text { with family }\end{array}$} & \multirow[t]{2}{*}{ Cultivar } & \multicolumn{2}{|c|}{ No. of plants } & \multirow{2}{*}{$\begin{array}{c}\% \text { of the } \\
\text { transmission }\end{array}$} & \multirow{2}{*}{$\begin{array}{l}\text { Incubation } \\
\text { period } \\
\text { (Days) }\end{array}$} & \multirow[t]{2}{*}{ Symptoms } \\
\hline & & & Inoculated & Infected & & & \\
\hline 1. & \multicolumn{7}{|l|}{ Leguminoceae } \\
\hline a) & Glycine max & JS-335 & 5 & 5 & 100 & 15 & $\begin{array}{l}\text { Systemic, mosaic } \\
\text { chlorotic }\end{array}$ \\
\hline b) & Glycine $\max$ & MACS-13 & 5 & 4 & 80 & 20 & mosaic, distorted leaf \\
\hline c) & Dolichos lablab & Local & 5 & 4 & 80 & 18 & $\begin{array}{l}\text { Dark green } \\
\text { Mosaic }\end{array}$ \\
\hline d) & Phaseolu vulgars & Arkakomal & 5 & 4 & 80 & 17 & Systemic, mottling \\
\hline e) & Vigna ungiculata & C-152 & 5 & 4 & 80 & 15 & Mosaic, mottling. \\
\hline 2. & \multicolumn{6}{|l|}{ Solanaceae } & \\
\hline a) & Datura stramonm & Local & 5 & 2 & 40 & 15 & $\begin{array}{l}\text { Chlorotic spots and } \\
\text { vein clearing }\end{array}$ \\
\hline 3. & \multicolumn{6}{|l|}{ Cucurbitaceae } & \\
\hline a) & Cucumis sativus & $\begin{array}{l}\text { Phule } \\
\text { champa }\end{array}$ & 5 & 4 & 80 & $12-15$ & $\begin{array}{l}\text { Mosaic and mottling } \\
\text { symptoms }\end{array}$ \\
\hline 4. & \multicolumn{6}{|l|}{ Chenopodiaceae } & \\
\hline a) & $\begin{array}{l}\text { Chenopodium } \\
\text { Amaranticolor }\end{array}$ & Local & 5 & 3 & 60 & $10-12$ & $\begin{array}{l}\text { Small chlorotic local } \\
\text { lesion }\end{array}$ \\
\hline
\end{tabular}


On cowpea, the virus produced chlorotic spots and yellowing within 15 days of incubation with 80 per cent transmission (Fig. 2-H). Cucumber expressed mild chlorotic spots with 80 per cent (Fig. 1-A1, A2 and B) transmission within 12-20 days of incubation. Infected pea leaves showing light green mosaic symptoms.

Limited host range of soybean mosaic virus has also been reported by a few workers. Pierce (1935) and Kendrick and Gardner (1924) reported that the soybean mosaic virus had a limited host range restricted to soybean only. Nariani and Pingaley (1960) also stated that except soybean none of the 64 plants species belonging to different families tested either developed any symptoms of SMV or carried the virus symptomlessly.

Similarly, several other workers have reported a narrow host range of the Virus restricted only to Leguminaceae (Byadagi and Patil 2005; Bos 1972; Lockhart and Fischer 1976; Castano et al., 1982; Anjos et al., 1985 and Naik and Keshavmurthy 1992).

\section{References}

Anjos, J. R., M.T.Lin and E.W. Kitajima. 1985. Characterization of an isolate of soybean mosaic virus. Fitopatologia Brasileria, 10(1): 143-157.

Boss, L. 1972. Soybean mosaic virus: Description of Plant Viruses, No. 93. Commonwealth Mycological Institute and Association of Applied Biologists, Kew, England.

Castano, J.M., M.P.J. Tamayo and F.J Morales.1982, Monroe bean (Phaseolus vulgaris) a local lesion assay variety for bean common mosaic and soybean mosaic viruses. Turrialba, 32: 329-332.

Kendrick, J.B. and M.W. Gardner. 1924. Soybean mosaic. Seed transmission and effect on yield. Journal of Agricultural Research, 27:91-98.

Lockhart, B.E. and H.V. Fischer.1976. Identification of soybean mosaic virus in Morocco. Plant Disease Reporter, 60:260261.

Mali, V.R. 1995: Profile of viruses naturally infecting soybean in Marathawada. Proceedings of the 10th Annual Convention Indian Society for Virology and National Symposium: Viral Diseases of SocioEconomic Importance Relevant to India, Jan. 16-18, SCTIMST, Dept. Microbiol, Trivandrum, India, pp: 34

Naik, R.G. and R.V. Keshavmurthy. 1992. Characterization of a virus causing mosaic on soybean [Glycene $\max (\mathrm{L}$.) Merr.] From Karnataka. Legume Research, 15(1): 19-23.

Nariani, T.K. and K.V. Pingale. 1960. A mosaic disease of Soybean [Glycene $\max$ (L.) Merr]. Indian Phytopathology, 13: 130-136.

Patil, R.G. and A.S.Byadgi. 2005. Transmission Studies of Soybean mosaic virus Karnataka J. Agric. Sci., 18(1): (52-54) 2005.

Pierce, W.H. 1935. The identification of certain virus infecting leguminous plants. Journal of Agricultural Research 51: 1017-1039.

Singh, B.R., O.K.Singh and H.K.Saxena. 1976. A mosaic disease of soybean at Kanpur, India. Science and Culture, 42: 53-54.

Usman, K.M., K. Ranganathan., T.K. Kandaswamy., A.P.S. Damodaran and R. Ayyvoo. 1973. Studies on a mosaic disease of soybean. Madras Agricultural Journal, 60:472-474.

\section{How to cite this article:}

Nandakishor, H.V., B. Kumaraswamy, S.S. Mane and Amrutha Veena, G. 2017. Host Range Studies of Soybean Mosaic Virus. Int.J.Curr.Microbiol.App.Sci. 6(7): 304-308. doi: https://doi.org/10.20546/ijcmas.2017.607.035 